\title{
高強度のプレキャストコンクリートを使用した 超高層集合住宅の施工
}

関口 博*1 • 戸田光夫*2 ・萩原 浩*3 ・梶田秀幸*4

\section{1.はじめに}

本建物の計画地は, 南千住駅の東側に位置し,「南千 住地区住宅市街地総合整備事業」の整備計画の一部に位 置づけられたものである。当街区の事業主体は, 東京都 住宅局, 東京都住宅供給公社扔よび都市基盤整備公団

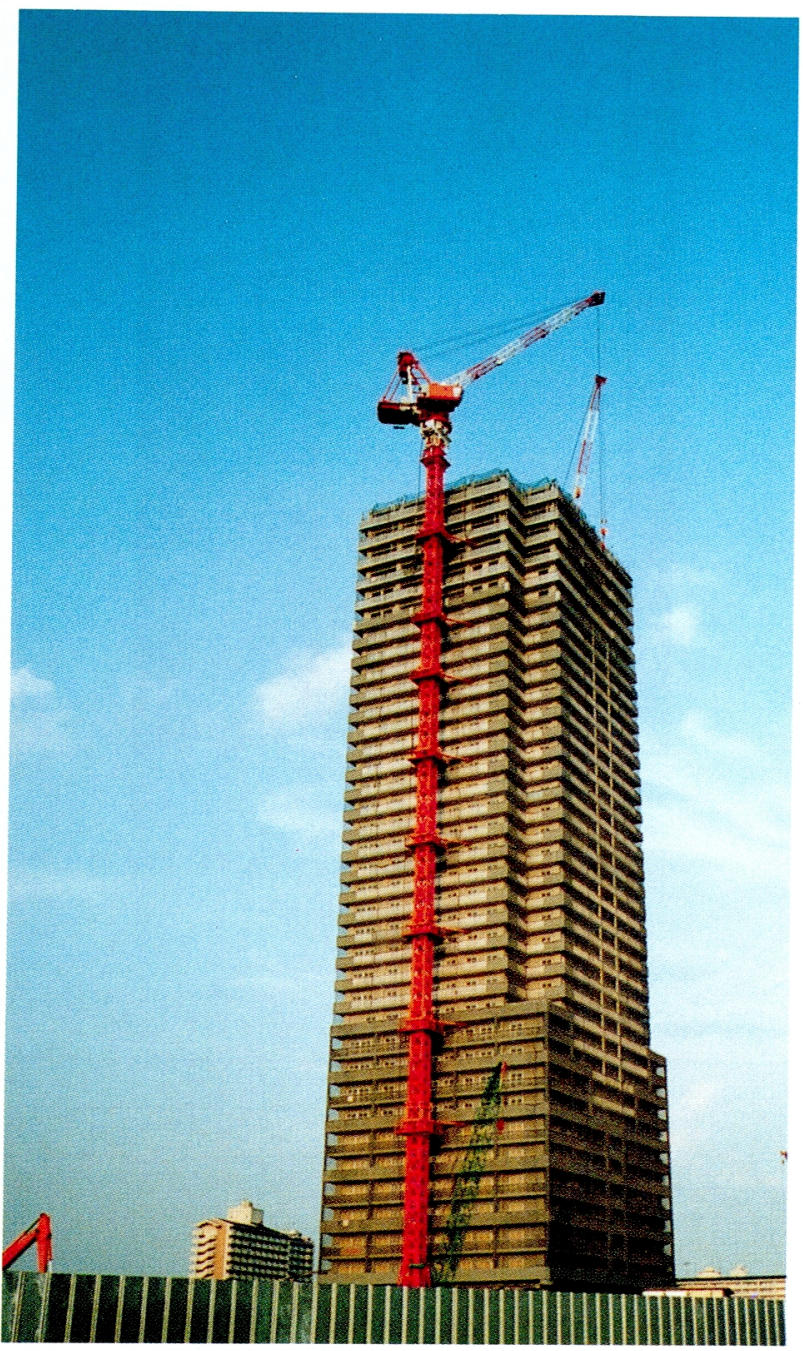

写真-1 建物 全 景

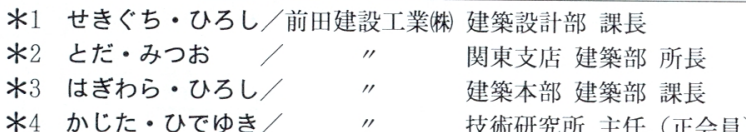

（旧住宅・都市整備公団）であり，超高層住宅 3 棟之， 高層住宅 1 棟が配置されている。

今回報告する建物は，都市基盤整備公団による地上 39 階建ての $\mathrm{RC}$ 造による超高層集合住宅であり、この 住宅棟に採用したプレキャスト工法扔よび高強度コンク リート技術について以下に記述する。

\section{2. 建物 概 要}

建物の施工状沉を写真-1に示す。建物概要は表-1 の と扔りであるが，住戸は平面的にU 字型に配置された 全 498 戸の賃貸住宅である。

3. 構造設計概要

基準階伏図を図-1 に示す。構造形式は，純ラーメン

表-1 建物概要

\begin{tabular}{|c|c|}
\hline 工 事 名 称 & 南千住 E 街区北棟 (民開) 建設工事 \\
\hline 建＼cjkstart設 & 東京都荒川区南千住 4 丁目 346 番 11 \\
\hline 注 & 都市基盤整備公囘 東京支社 \\
\hline 設計者・施工者 & 前田・西松・五洋建設共同企業体 \\
\hline 工 事 監 理 者 & 都市基盤整備公団＼cjkstart東京支社 \\
\hline 途 & 共同住宅 \\
\hline 規 & 地上 39 階 塔屋 1 階 \\
\hline 延面積・最高高さ & $43264.85 \mathrm{~m}^{2} \cdot 129.597 \mathrm{~m}$ \\
\hline 構 造 形 式 & 鉄筋コンクリート造 \\
\hline
\end{tabular}

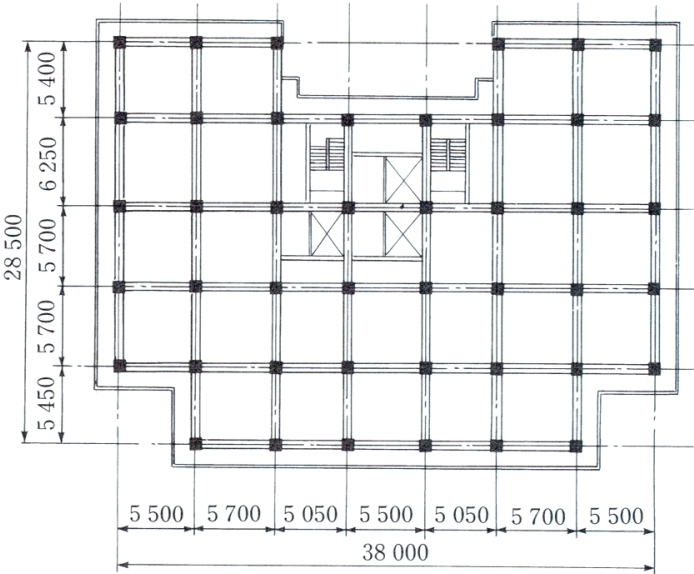

図-1 基準階はり伏図 


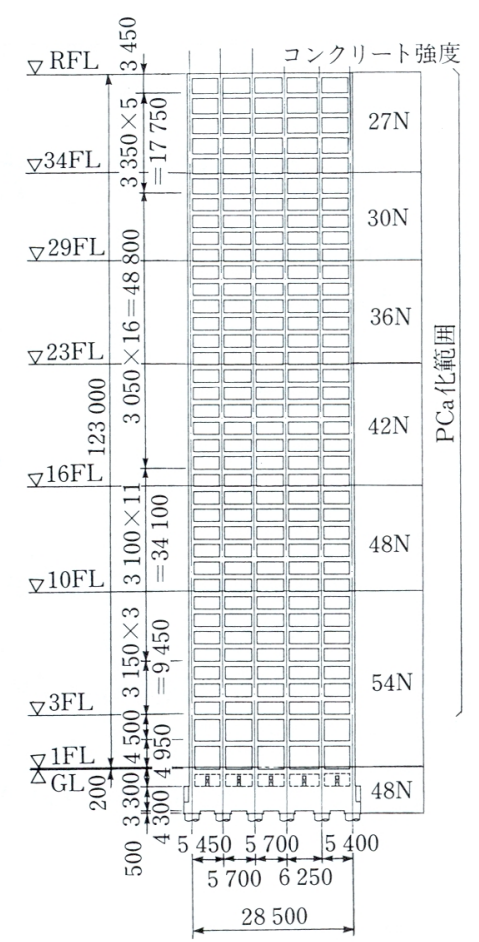

図-2＼cjkstart軸組図（コンクリート強度区分）

とし，はり降伏先行型で計画している。スパンは, 超高 層 $\mathrm{RC}$ 造としてはごく一般的な $5.05 \mathrm{~m} \sim 6.25 \mathrm{~m}$ である。 部材断面寸法は，柱で 1 階の $1000 \times 1000 \mathrm{~mm}$ から最上 階の $750 \times 750 \mathrm{~mm}$ まで順次絞っている。それに伴って, はりも $580 \times 950 \mathrm{~mm}$ から $480 \times 800 \mathrm{~mm}$ まで同様に筊っ ている。使用材料としては, コンクリートでは $F_{c}$ $=54 \sim 27 \mathrm{~N} / \mathrm{mm}^{2}$ (強度分布を図-2に示す)。鉄筋では, 主筋はSD 490(D41) から SD 345(D25)，女九断補強筋 は降伏強度 685 級の異形棒鋼を使用している。PCa 化 した構造部材は，3階より上の柱・大ばり・小ばり・ス ラブ・バルコニーであるが，このうち柱については，サ イト PCa とした。主筋の継手については，柱はスリー ブショョント，はりは仕口部内での溶接継手とした。

\section{4. 施工 概 要}

1フロアーを A・B の 2 工区分割し, 両工区に JCC $200(32 \mathrm{~m} \times 6.0 \mathrm{t}$ 吊）タワークレーンと，JCC 230（32 $\mathrm{m} \times 7.0 \mathrm{t}$ 吊) タワークレーンを 1 台, 計 2 台を設置し た。ヤードには柱 PCa の製作および搬送資材の荷取合 番用として 50 tクローラークレーン 1 台を常設した。

コンクリート打設は, バイブレーター付バケット（2.8 $\mathrm{m}^{3}$ ) 2 基の交互使用により行った。

\section{1 サイクル工程}

表-2 に躯体サイクル工程を, 図-3に躯体サイクル概 念を示す。表-2 に示すように A 工区之B工区のサイク ルのずれを 1 日とし, 1 フロアーの躯体サイクル工程を 1 工区 6 日とした。またサイクル工程 3 日目の床 $\mathrm{PCa}$ セットと什上げ材先行揚重作業を調整することで雨天, 強風による工程遅延を回避することとした。

\section{2 PCa 工法の採用}

大ばり (2 120 ピース), 小ばり (181ピース), 一般 床 (2 402 ピース) はハーフ PCa 部材, バルコニー

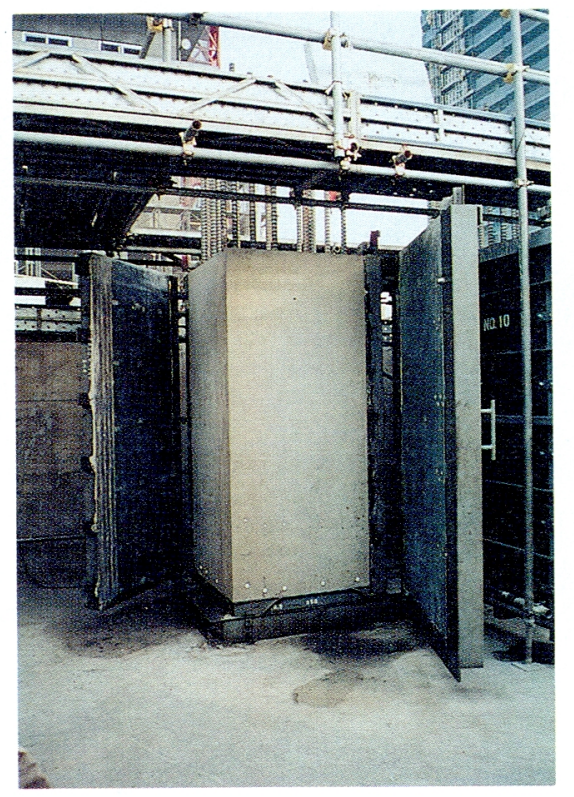

写真-2 型枠状 況

表-2 躯体サイクル工程表






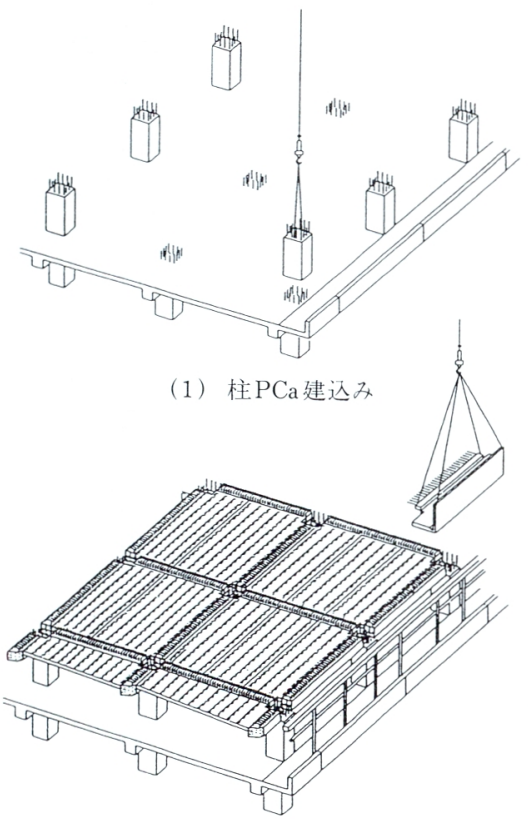

(4) フルPCaバルコニー取付け

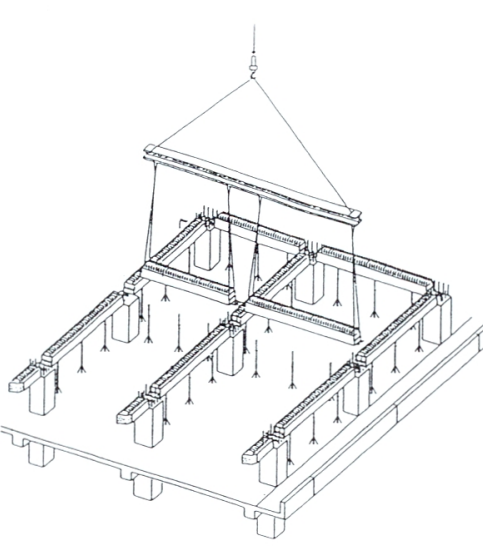

（2）はり PCa 架設

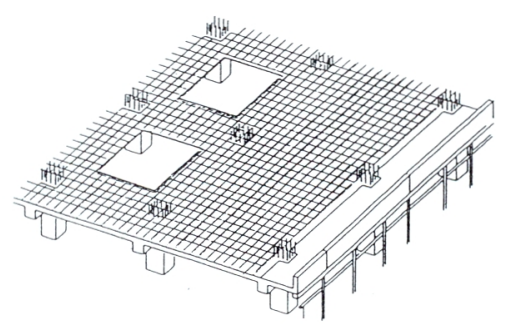

(5) スラブ配筋

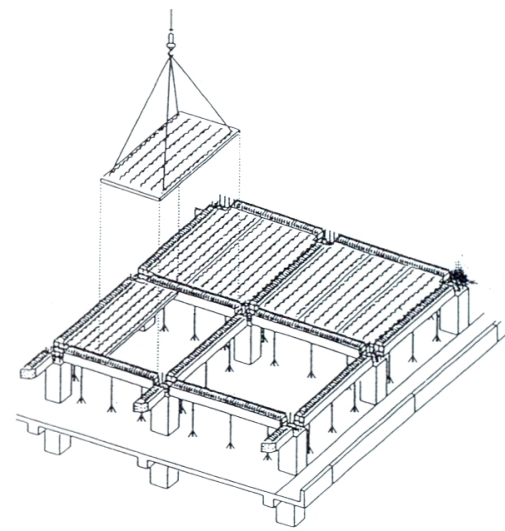

(3) 半 PCa床板取付



(6) コンクリート打設

図-3＼cjkstart躯体サイクル概念図

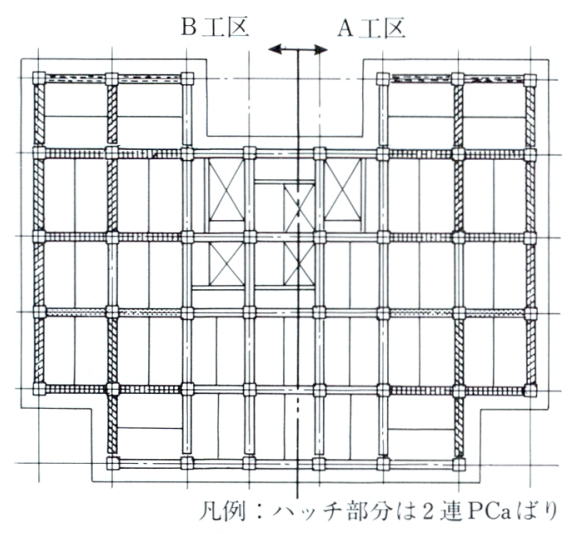

図-4 工区割・PCa 割付図

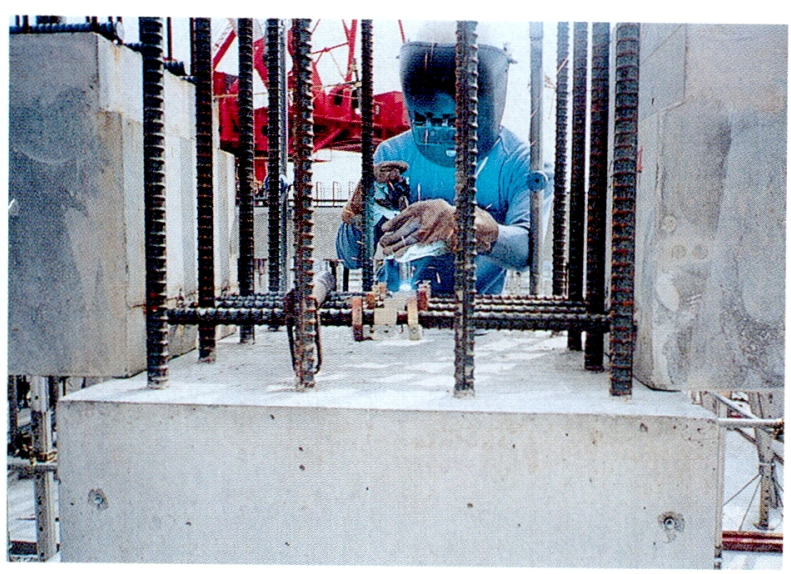

写真-3 CB 溶接状況

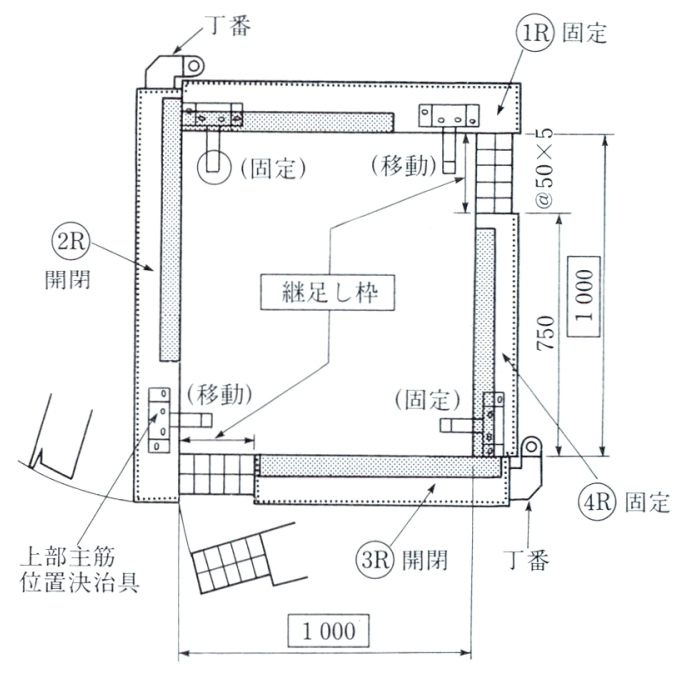

図-5 柱型枠断面図

(917ピース) はフル $\mathrm{PCa}$ 部材とし，その他 30 ピース を含め合計 5650 ピースを工場製作とした。

図-4に $\mathrm{PCa}$ 割付図を示す。タワークレーンに近い大 ばりについては，2 連の PCa 部材にて割付けた。

柱（1 664 ピース）は，現場製作のフル $\mathrm{PCa}$ とした。 柱 $\mathrm{PCa}$ を製作するにあたり，二方向断面変化型の開 閉式型枠の開発を行い実施工へ展開した。

この柱型枠は，4面のうち，２面をL 型で固定し，他 の 2 面を丁番による開閉式の鋼製型枠とした。丁番式開 閉型枠にすることにより, 型枠の脱型, 組立効率が向上 し，省力化および作業の単純化が可能となった。 柱断面形状が $1000 \times 1000 \mathrm{~mm}$ から $750 \times 750 \mathrm{~mm}$ ま 




(1) 脱 枠

柱PCa 吊込みストックヤード仮置



(4) 柱鉄筋七ット固定 インサート類取付け

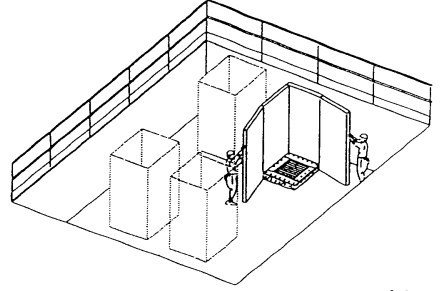

（2）型枠断面組替 (断面変更の場合) 型枠ケレン・清掃剥離剤塗布



(5) 型枠組立て

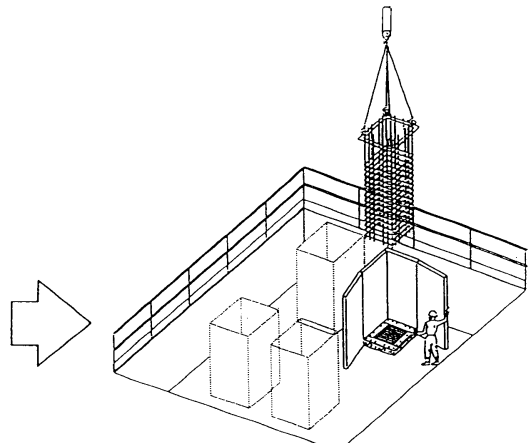

(3) 柱鉄筋吊込み

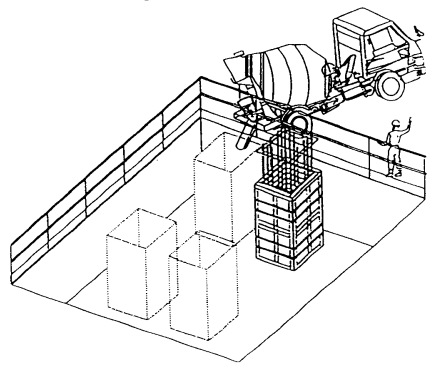

(6) コンクリート打設 天端均し養生

図-6 柱サイト PCa 製作手順図

での 6 段階および高さが 2180 と 2730 の 2 段階で変化 していくため, 継足し枠 $(50 \mathrm{~mm} \times 5)$ を設置して， そ の変化に合わせて継足し枠を取外すだけで二方向断面変 化に対応するようにした（図-5参照）。

二方向断面変化型の開閉式サイト PCa 型枠を使用す ることにより大幅な省力化が図られ，12 本／日の柱サ イト PCa 製作が可能となった。

図-6で柱サイト PCa 製作手順の概念図を示し, 型枠 状況を写真-2で示す。

躯体の $\mathrm{PCa}$ 化率を高くし，現場打ちコンクリートを 最小限に抑えることで工程の短縮を図ることができた。

\section{3 C B 工法}

はり主筋の継手の溶接工法においては, 裏当て材とし てセラミックス材を使用する狭開先半自動アーク溶接工 法（CB工法 ; A 級継手）を採用した。

$\mathrm{CB}$ 工法の特徵は, 裏当て材を溶接後除去することに より外観検查が可能となり，信頼性が増すことにある。

今回は写真-3に示すように, 柱はり接合部での溶接 作業もあることから，同条件下での技量試験，実物大施 工実験を経て，実施工に臨んだ。

CB 継手施工数および，UT 試験結果を表-3に示す。 溶接不良は 4,5 階はりの太径鉄筋で $1 \%$ 程度発生した が，6階以降は作業の習熟効果むあり，ほぼ不良率は，0 となった。また，当初懸念された高層ゆえの強風による 溶接不良については, 簡易な風養生対策でも十分に防ぐ ことができ，信頼性のある鉄筋継手を実現できた。

\section{5. コンクリート工事}

本工事に使用するコンクリートの $F_{c}$ は 54 ～27 N/
表-3 CB 継手施工・UT 試験結果

\begin{tabular}{|c|c|c|c|c|c|c|}
\hline & \multicolumn{2}{|c|}{ 継手数量 (箇所) } & \multirow{2}{*}{$\begin{array}{l}\text { UT 箇所数 } \\
\text { (箇所) }\end{array}$} & \multirow{2}{*}{$\begin{array}{c}\text { 検查率 } \\
(\%)\end{array}$} & \multirow{2}{*}{$\begin{array}{l}\text { 不良数 } \\
\text { (箇所) }\end{array}$} & \multirow{2}{*}{$\begin{array}{c}\text { 不良率 } \\
(\%)\end{array}$} \\
\hline & SD 390 & $\mathrm{SD} 345$ & & & & \\
\hline D $38+$ D 38 & 9010 & & 7204 & 80.0 & 31 & 0.4 \\
\hline D $35+$ D 35 & 2910 & & 1907 & 65.5 & 6 & 0.3 \\
\hline D $32+$ D 32 & 2904 & & 1812 & 62.4 & 0 & 0.0 \\
\hline D $29+$ & 1384 & & 920 & 66.5 & 0 & 0.0 \\
\hline D $25+$ D 25 & & 1 & 844 & 58.2 & 0 & 0.0 \\
\hline 計 & & & 12687 & 71.8 & 37 & 0.3 \\
\hline
\end{tabular}

$\mathrm{mm}^{2}$ である。1997 年の JASS 5 によると, 高強度コン クリートは $F_{c}$ が $36 \mathrm{~N} / \mathrm{mm}^{2}$ を超えるコンクリートであ ることから，それに従って， $F_{c}=54 ， 48,42 \mathrm{~N} / \mathrm{mm}^{2}$ の コンクリートを高強度コンクリート, $F_{c}=36,30,27 \mathrm{~N}$ $/ \mathrm{mm}^{2}$ のコンクリートを通常の強度のコンクリートとし て, 調合設計および品質管理等を行った。なお, レディー ミクストコンクリート工場（以下，生コン工場と略記） は, 不測の事態によって供給が帯ることのないよう, 複 数の生コン工場から供給する体制をとった。

\section{1 高強度コンクリートの事前検討}

高強度コンクリートにおける使用材料の選定, 調合の 検討および施工性の確認を目的に，室内および実機によ る試験練り，実大規模の模擬柱による施工実験を行った。 実機試験練りは, 夏期, 冬期, 標準期において実施し, 季節ごとに, 水セメント比と強度の関係, 構造体コンク リート強度と管理用供試体強度との強度差（S 值）およ びフレッシュコンクリートの品質変化等を把握した。

\section{2 コンクリートの使用材料および調合}

高強度コンクリートは, 事前検討の結果および生コン 
工場の実績等から，使用材料抢よび調合を表-4, 表-5 に示すとおりとした。また，通常の強度のコンクリート は，生コン工場の標準調合によって製造することとした。

\section{3 コンクリートの打込み}

コンクリートの打込みは, 地下 1 階立上がり部分 （VH一体打設）を除き, 地上 2 階までは $\mathrm{VH}$ 分離打設 工法を採用した。また, 地上 2 階まではコンクリートポ ンプにより打設し，3階以上はバケットによって打設し た。なお，4.2 章で述べたように，3階以上の柱 $(\mathrm{V}$ 部) はサイトプレキャストとしており，現場敷地内において 製作した。

表-4＼cjkstart高強度コンクリートの使用材料

\begin{tabular}{|c|c|c|c|c|}
\hline $\begin{array}{l}\text { 生コン } \\
\text { エ 場 }\end{array}$ & \multicolumn{3}{|c|}{ 料 } & 記号 \\
\hline \multirow{5}{*}{ A工場 } & \multirow{2}{*}{ セメント } & \multicolumn{2}{|c|}{ 普通ポルトランドセメント＼cjkstart比重 3.16} & $\mathrm{NC}$ \\
\hline & & \multicolumn{2}{|c|}{ 低熱ポルトランドセメント＼cjkstart比重 3.22} & $\mathrm{LC}$ \\
\hline & 紐骨材 & $\begin{array}{l}\text { 栃木県葛生産砕砂（石灰岩） } \\
\text { 千葉県市原产陸砂 }\end{array}$ & \begin{tabular}{|l} 
混合砂 \\
比重 2.62
\end{tabular} & S \\
\hline & 粗骨材 & \multicolumn{2}{|c|}{ 杤木県岩舟産哗石（硬質砂岩） 此重 2.70} & G \\
\hline & 混和剂 & \multicolumn{2}{|c|}{ 高性能 $\mathrm{AE}$ 減水剂（ポリカルボン酸系） } & $\mathrm{HAE}$ \\
\hline \multirow{5}{*}{ H工場 } & \multirow{2}{*}{ セメント } & \multicolumn{2}{|c|}{ 普通ポルトランドセメント＼cjkstart比重 3.15} & $\mathrm{NC}$ \\
\hline & & \multicolumn{2}{|c|}{ 低熱ポルトランドセメント＼cjkstart此重 3.22} & $\mathrm{LC}$ \\
\hline & 紐骨材 & $\begin{array}{l}\text { 栃木県葛生産砕仯（石灰岩） } \\
\text { 茨城県鹿島産陸砂 }\end{array}$ & $\begin{array}{l}\text { 混合仯 } \\
\text { 比重 } 2.62\end{array}$ & S \\
\hline & 粗骨材 & \multicolumn{2}{|c|}{ 杤木県葛生産碀石（石炭岩） 比重 2.70} & G \\
\hline & 混和剂 & \multicolumn{2}{|c|}{ 高性能 $\mathrm{AE}$ 減水剂（ポリカルボン酸系） } & HAE \\
\hline
\end{tabular}

\section{4 コンクリートの品質管理および体制}

コンクリートの品質管理は JASS 5 および当社規準 に準じて実施した。高強度コンクリートにおける主な検 査方法を表-6, 表-7に示す。日常の管理に関しては, コンクリートの品質管理専任者を現場や生コン工場に配 して管理を行い, フレッシュコンクリート試験等は現場 に設けた試験室において実施し，コンリートの品質変化 に迅速に対応した。すべての試験結果はイントラネット により, 施工者だけでなく各関連部所（設計部や技術研 究所）の担当者がすぐに確認できるようにし，支援体制 の充実を図った。また, 監理者, 施工者, 生コン工場打 よび各関連部署の担当者を集め, 定期的にコンクリート の品質管理に対する検討会を開催し, 品質管理の状況に ついて把握するとともに, 発生する諸問題に対応した。

\section{5 コンクリートの品質管理結果}

高強度コンクリートに関しては, 荷卸し地点における $\mathrm{A}$ 工場のフレッシュコンクリート試験結果の一部を図 -7に示す。スランプ, スランプフロー, 空気量および 水セメント比はいずれの試験結果においても判定基準を 満足するものであった。ただし, 空気量に関しては, 強 度への影響を考慮したため中心值から下限值の間に偏る 傾向が見受けられた。強度管理の結果に関しては, A 工場の試験結果の一部を図-8 に示す。全般に強度は高 く，使用するコンクリートの一部に判定基準を下回るむ のがあったものの, 構造体コンクリートにおいてはすべ て判定基準を満足した。

表-5＼cjkstart高強度コンクリートの調合

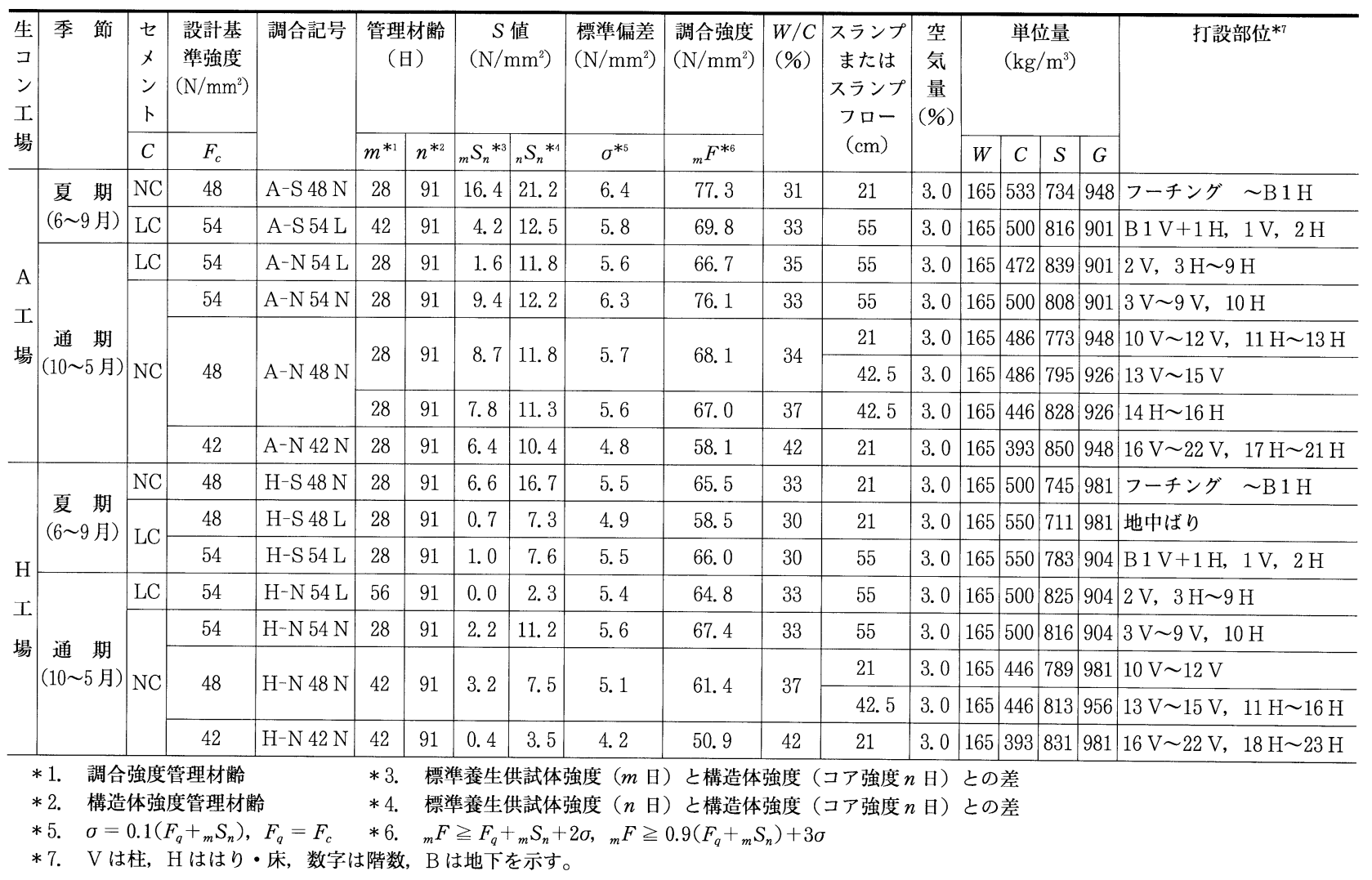


表-6＼cjkstart高強度コンクリートにおける荷卸し地点でのフレッシュ コンクリートの検査方法

\begin{tabular}{|c|c|c|c|}
\hline 目 & 試験 - 検査方法 & 時期 - 回数 & 判定基準 \\
\hline スランプ & JIS A 1101 & \multirow{2}{*}{$\begin{array}{l}\text { 打込み当初（最初 } \\
\text { の } 5 \text { 台）は生コン } \\
\text { 車全車。品質が安 } \\
\text { 定したら, 圧縮強 } \\
\text { 度供試体採取時。 }\end{array}$} & 所要値 $\pm 2.5 \mathrm{~cm}$ \\
\hline $\begin{array}{l}\text { スランプフ } \\
\text { ロー }\end{array}$ & JASS 5 T-503 & & 所要值 $\pm 7.5 \mathrm{~cm}$ \\
\hline 空気量 & JIS A 1118 & \multirow{3}{*}{$\begin{array}{l}\text { 圧縮強度供試体採 } \\
\text { 取時。 }\end{array}$} & $\begin{array}{l}\text { 指定した空気量 } \\
\pm 1.5 \%\end{array}$ \\
\hline $\begin{array}{l}\text { コンクリー } \\
\text { ト温度 }\end{array}$ & $\begin{array}{l}\text { 棒状温度計によ } \\
\text { る測定 }\end{array}$ & & $35^{\circ} \mathrm{C}$ 以下 \\
\hline $\begin{array}{l}\text { 水セメント } \\
\text { 比*1 }\end{array}$ & $\begin{array}{l}\text { 高周波加熱乾燥 } \\
\text { 法*2による測定 }\end{array}$ & & $\begin{array}{c}\text { 指定した水セメン } \\
\text { 卜比 }+3 \% \text { 以下 }\end{array}$ \\
\hline 塩化物量 & JASS 5 T-502 & $\begin{array}{l}\text { （i ） 海仯など塩 } \\
\text { 化物を含む抢それ } \\
\text { のある骨材の場合 } \\
\text { は打込み当初およ } \\
\text { び } 150 \mathrm{~m}^{3} に 1 \text { 回 } \\
\text { 以上 } \\
\text { (ii) その他の場 } \\
\text { 合 } 1 \text { 日 } 1 \text { 回以上 }\end{array}$ & $0.2 \mathrm{~kg} / \mathrm{m}^{3}$ 以下 \\
\hline
\end{tabular}

*1. 単位水量の変動把握のための試験

*2. 日本建築学会「高性能 $\mathrm{AE}$ 隇水剂コンクリートの調合・製造お よび施工指針・同解説」付録。フレッシュコンクリートの単位水 量推定試験方法

表-7＼cjkstart高強度コンクリートにおける圧縮強度の検査方法

\begin{tabular}{|c|c|c|c|c|}
\hline 管理目的 & 試験材齢 & 盖生方法 & 試験回数 & 判定基準 \\
\hline $\begin{array}{l}\text { 使用する } \\
\text { コンクリー } \\
\text { トの品質 } \\
\text { 管理 }\end{array}$ & $7 m$ 日 & \multirow{2}{*}{ 標準盖生 } & \multirow{2}{*}{$\begin{array}{l}\text { 打込み工区 } \\
\text { かつ打込み } \\
\text { 日を } 1 \text { 検査 } \\
\text { ロットとし, } \\
1 \text { 回/ } / 100 \mathrm{~m}^{3} \\
\text { 以上かつ } 3 \\
\text { 回以上 }\end{array}$} & $\begin{array}{l}\bar{X}-\left(K-K_{\alpha} / \sqrt{N}\right) \sigma \\
\quad \geqq F_{q}+{ }_{m} S_{n} \\
X_{\min } \geqq 0.9\left(F_{q}+{ }_{m} S_{n}\right)\end{array}$ \\
\hline $\begin{array}{l}\text { 構造体コ } \\
\text { ンクリー } \\
\text { トの強度 } \\
\text { 管理 }\end{array}$ & $n$ 日 & & & $\begin{array}{l}\bar{X}-\left(K-K_{\alpha} / \sqrt{N}\right) \sigma \\
\quad \geqq F_{q}+{ }_{n} S_{n}\end{array}$ \\
\hline
\end{tabular}

$\bar{X}=-\sum_{N_{i}=1}^{1 N} X_{i}:$ 圧縮強度の $N$ 回の試験の平均値 $\left(X_{i}\right.$ は圧縮強度 1 回の試験の値)

${ }_{m} S_{n}$ : 標準養生供試体強度 $(m$ 日) と構造体強度（コア 強度 $n$ 日）との差

${ }_{n} S_{n}$ ：標淮養生供試体強度 $(n$ 日） と構造体強度（コア 強度 $n$ 日）との差

$F_{q}=F_{c}$ : 品質基準強度 $\quad K: 2.00 \quad K_{\alpha}: 1.64$ $\sigma=0.1\left(F_{q}+{ }_{m} S_{n}\right):$ 標準偏差

通常の強度のコンクリートにおいても，フレッシュコ ンクリート試験および強度試験の結果は，すべて判定基 準を満足する屯のであった。

6. おわりに

本工事の施工にあたり，柱サイト PCa を含めた全部 材の PCa 化施工，およびはり主筋の柱内接合を採用し た結果，躯体精度が確保でき，工期短縮が可能となった。

コンクリートに関しては，基本的に JASS 5 に準じ て，使用材料および調合を設定し，製造，打設および品 質管理等を行った。また，品質管理に対する支援体制の 充実を図り，発生する諸問題に迅速に対応した。その結 果，いずれの調合のコンクリートにおいても，すべての 試験において判定基準を満足することができ，高品質の
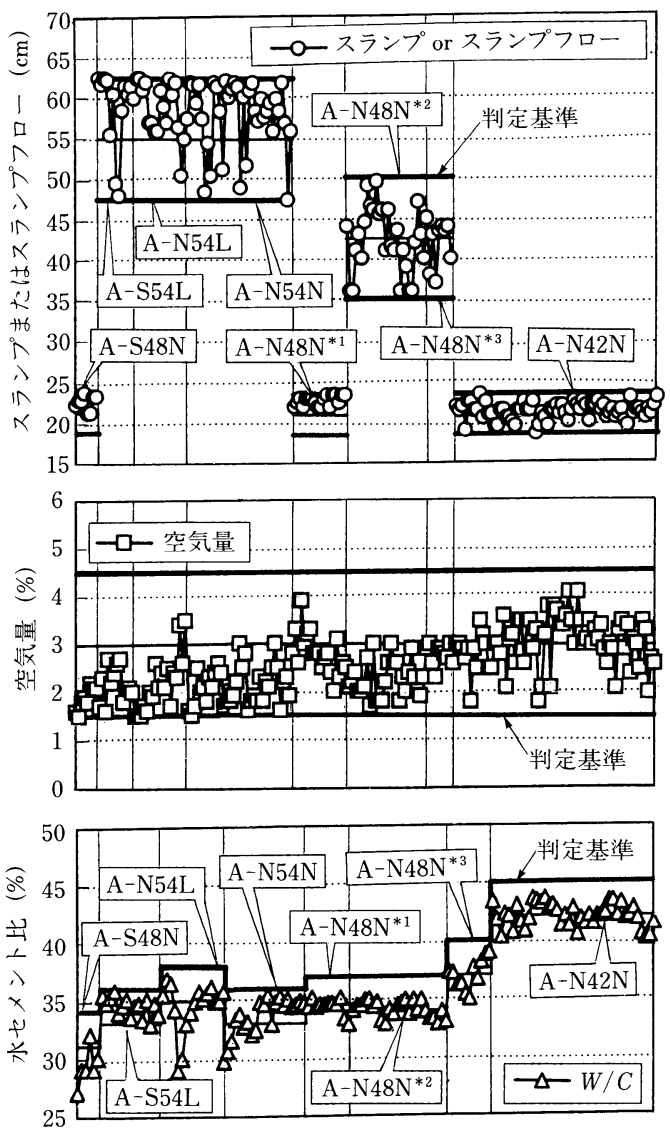

*1. $W / C=34 \%$, スランプ $21 \mathrm{~cm} \quad * 2 . W / C=34 \%$, フロー $42.5 \mathrm{~cm}$ *3. $W / C=37 \%$, フロー $42.5 \mathrm{~cm}$

図-7Ａ工場の高強度コンクリートにおける フレッシュコンクリート試験結果
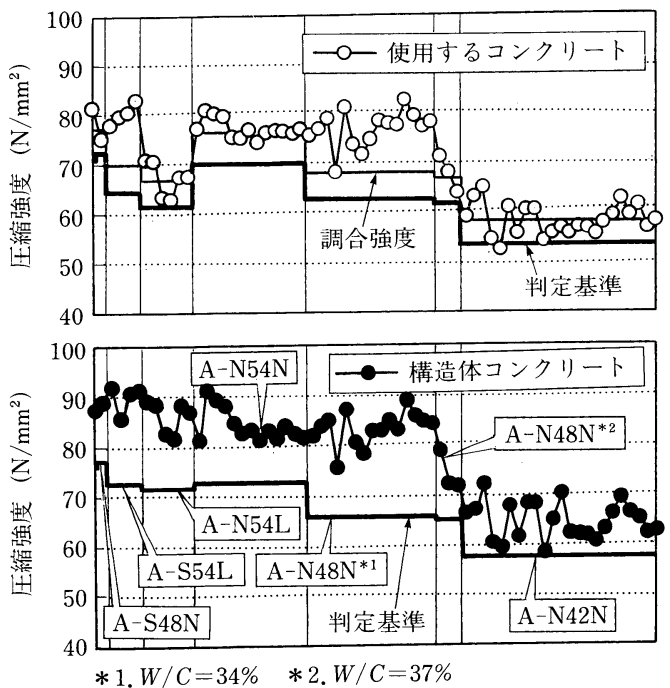

図-8Ａ工場の高強度コンクリートにおける強度試験結果

構造体コンクリートを構築することができた。

謝 辞 本工事の施工に関して，ご指導いただいた愛 知工業大学 尾形教授, ご協力いただいたアサノコンク リート(株)深川工場, 日立コンクリート(株)押上工場, 竹本油脂(株), (株) ポゾリス物産, (株) 日東コンクリー 卜技術事務所他の関係各位に深く感謝の意を表します。 